\title{
PELAKSANAAN KURIKULUM 2013 REVISI MELALUI IMPLEMENTASI SCIENTIFIC APPROACH DI SMA KABUPATEN PACITAN
}

\author{
Ani Rakhmawati, Budhi Setiawan, Kundharu Saddhono \\ Universitas Sebelas Maret \\ Email: anirakhmawati@staff.uns.ac.id
}

\begin{abstract}
Abstrak
Kurikulum 2013 diharapkan dapat menghasilkan insan Indonesia yang produktif, kreatif, inovatif, afektif melalui penguatan sikap, keterampilan, dan pengetahuan yang terintegrasi. Pengembangan Kurikulum 2013 revisi diharapkan dapat mengatasi kelemahan-kelemahan yang ada pada kurikulum sebelumnya. Langkah awal yang telah dilakukan dalam rangka persiapan implementasi Kurikulum 2013 revisi adalah melakukan Pendidikan dan Pelatihan dalam rangka Implementasi Kurikulum 2013 revisi kepada seluruh unsur pendidikan, dalam hal ini pendidik dan tenaga kependidikan di sekolah serta unsur-unsur lain yang terlibat langsung dalam proses pendidikan. Salah satu strategi untuk memahami dan memantapkan implementasi Kurikulum 2013 revisi, yaitu melalui Pendidikan dan Pelatihan (Diklat) Implementasi Kurikulum 2013 revisi yang diperuntukkan bagi guru, Kepala Sekolah dan Pengawas Sekolah. Implementasi kurikulum 2013 sangat menarik untuk didiskusikan dalam berbagai konteks pembelajaran di Sekolah Menengah Atas. Ada tiga aspek utama dalam implementasi kurikulum 2013, yakni: (1) perubahan mind set, (2) keterampilan dan kompetensi guru, (3) kepemimpinan, kultur, dan manajemen sekolah. Ketiga komponen tersebut menjadi dasar perubahan yang ingin dicapai dalam kurikulum 2013. Kegiatan PKM ini dilaksanakan di SMA Kabupaten Pacitan. Terdapat tiga tahap dalam pelaksanaan PKM, yaitu persiapan, pelaksanaan, dan evaluasi. Tahap persiapan merupakan tahap melakukan survei ke lokasi PKM untuk mendapatkan data awal dan dilanjutkan menysuun rencana kegiatan PKM sesuai dengan kondisi permasalahan yang dihadapi sekolah dalam pelaksanaan Kurikulum 2013 revisi yang pada umumnya masih belum banyak mengimplementasikannya di Kabupaten Pacitan. Tahap pelaksanaan merupakan tahap inti dari PKM. Kegiatan inti adalah pendampingan pelaksanaan kurikulum 2013 revisi dengan menggunakan scientific approach yang menjadi permasalahan utama yang dialami oleh guru-guru di Kabupaten Pacitan, Kegiatan inti ini berupa pelatihan, workshop, dan focus group discussion (FGD) yang dilakukan di Kabupaten Pacitan oleh Tim PKM dibantu oleh mahasiswa dalam pelaksanaan di lapangan. Tahap evaluasi adalah tahap akhir dari
\end{abstract}


PKM ini yang akan dilakukan oleh dosen dan mahasiswa mengenai penilaian terhadap apa yang telah dilakukan sebelum dan sesudah di sekolah serta keikutsertaan guru dan siswa dalam pelatihan dan bimbingan dalam implementasi Kurikulum 2013 revisi. Produk PKM kali ini terdiri dari modul implementasi kurikulum 2013 revisi menggunakan scientific approach dan artikel tentang kegiatan pendampingan implementasi kurikulum 2013 revisi dengan menggunakan scientific approach di SMA Kabupaten Pacitan yang dipublikasikan dalam jurnal nasional ber-ISSN.

Kata Kunci: Kurikulum 2013 Revisi, SMA, Scientific Approach, Implementasi

\section{PENDAHULUAN}

Rencana Pembangunan Jangka Menengah Nasional (RPJMN) tahun 2010. 2014 mengamanatkan perlu adanya penataan kembali kurikulum yang diterapkan saat ini berdasarkan hasil evaluasi kurikulum yang dilakukan oleh Pusat Kurikulum dan Perbukuan (Puskurbuk). Secara teoretik keberhasilan suatu kurikulum secara utuh memerlukan proses panjang, mulai dari kajian dan kristalisasi berbagai gagasan dan konsep ideal tentang pendidikan, pengembangan desain kurikulum, penyiapan dan penugasan pendidik dan tenaga kependidikan, penyediaan sarana dan prasarana, penyiapan tata kelola pelaksanaan kurikulum, pembelajaran, dan penilaian (Saddhono, 2014).

Pengembangan Kurikulum 2013 sudah mengalami beberapa revisi dari awal mulai diterapkan pada akhir 2013. Revisi yang dilakukan pada kurikulum 2013 meliputi perangkat pembelajaran guru, teknik penilaian, pendekatan dalam proses pembelajaran, silabus, terminology ujian, dan skala penilaian. Kurikulum 2013 revisi ini sampai sekarang sudah memasuki tahap implementasi bertahap-terbatas pada jenjang SD, SMP, dan SMA, pada sebagian kecil satuan pendidikan dasar dan menengah di seluruh wilayah Indonesia. Pentahapan implementasi ini, dimaksudkan untuk memperoleh informasi tingkat keterlaksanaan kurikulum dan memberi peluang bagi penyempurnaan kurikulum secara bertahap. Akan tetapi, implementasi kurikulum 2013. Akan tetapi, tahap implementasi kurikulum 2013 revisi masih belum berjalan efektif dan maksimal dikarenakan beberapa kendala, seperti keterbatasan informasi dan sosialiasi mengenai implementasi kurikulum 2013 revisi ke beberapa satuan pendidikan, salah satunya yang satuan pendidikan Sekolah Menengah Atas di Kabupten Pacitan.

Langkah awal yang telah dilakukan dalam rangka persiapan implementasi Kurikulum 2013 revisi adalah melakukan Pendidikan dan Pelatihan dalam rangka 
Implementasi Kurikulum 2013 revisi kepada seluruh unsur pendidikan, dalam hal ini pendidik dan tenaga kependidikan di sekolah serta unsur-unsur lain yang terlibat langsung dalam proses pendidikan. Salah satu strategi untuk memahami dan memantapkan implementasi Kurikulum 2013 revisi, yaitu melalui Pendidikan dan Pelatihan (Diklat) Implementasi Kurikulum 2013 revisi yang diperuntukkan bagi guru, Kepala Sekolah,dan Pengawas Sekolah yang terdapat di Kabupaten Pacitan.

Atas dasar itu, Diklat Implementasi Kurikulum 2013 merupakan langkah awal yang sangat penting untuk mempercepat pemahaman dan keterampilan dalam mengimplementasikan kurikulum tersebut. Untuk memelihara dan meningkatkan kesinambungan pemahaman dan implementasi Kurikulum 2013 revisi di masingmasing satuan pendidikan, diprogramkan kegiatan pendampingan untuk para guru dan kepala sekolah. Program pendampingan ini dilakukan sebagai penguatan dalam memahami konsep Kurikulum 2013 revisi di lapangan serta untuk membantu mengatasi berbagai kendala yang muncul pada saat implementasi kurikulum tersebut di sekolah.

Berdasarkan fenomena tersebut dapat dibayangkan bahwa masih banyak guru dan siswa yang masih buta berkaitan dengan kurikuum 2013 revisi ini. Padahal Kementerian Pendidikan dan Kebudayaan menyatakan bahwa tahun 2015, Kurikulum 2013 harus telah dilaksanakan di seluruh satuan pendidikan di Indonesia. Akan tetapi, pada kenyataanya sampai pada akhir tahun 2017, implementasi kurikulum 2013 revisi masih belum dapat terealisasi di sekolahsekolah secara maksimal.

Berkaitan dengan hal tersebut maka kegiatan PKM ini sangat perlu dilakukan dalam rangka menyukseskan penguatan pelaksanaan implementasi Kurikulum 2013 revisi di Kabupaten Pacitan. Pelaksanaan PKM ini tentu membantu dalam memberikan pemahaman bagi guru dan siswa berkaitan dengan Kurikulum 2013 revisi. Pelaksanaan PKM ini juga didukung oleh Dinas Pendidikan, Pemuda, dan Olahraga, MGMP tingkat SMA di Kabupaten Pacitan.

Selain itu, kegiatan PKM kali ini juga dilakukan untuk memberikan pengarahan kepada guru mengenai desain pembelajaran yang efektif dengan menggunakan pendekatan scientific approach. Pendekatan saintifik atau scientific approach merupakan desain pembelajaran yang dicanangkan oleh pemerintah seperti yang tedapat dalam draf kurikulum 2013 revisi. Dengan melakukan pendampingan pelaksaan kurikulum 2013 revisi di SMA Kabupaten Pacitan maka diharapkan para guru dan siswa SMA di Kabupten Pacitan dapat mengetahui secara komprehensif mengenai hakikat dan tata laksana kurikulum 2013 revisi dalam proses pembelajaran. Diharapkan setelah dilakukan pendampingan pelaksanaan 
Kurikulum 2013 revisi di SMA Kabupaten Pacitan, kurikulum 2013 revisi dapat terimplementasi dengan baik dan efektif di beberapa satuan pendidikan di Pacitan, khususnya Sekolah Menengah Atas (SMA). Kegiatan PKM ini juga dalam rangka meningkatkan kualitas pembelajaran di SMA, khususnya dengan menggunakan pendekatan scientific approach.

\section{METODE}

Kegiatan PKM tentang pendampingan pelaksanaan kurikulum 2013 revisi melalui scitentific approach dilaksanakan di beberapa Sekolah Menengah Atas di Kabupten Pacitan. Sekolah yang dipilih untuk menjadi lokasi penelitian adalah SMAN 1 Pacitan dan SMAN 2 Pacitan. Pemilihan kedua sekolah tersebut menjadi lokasi kegiatan PKM kali ini dikarenakan lokasi kedua sekolah tersebut paling mudah dijangkau, yaitu terdapat di wilayah kota Pacitan. Selain itu, kedua sekolah tersebut juga menjadi sekolah rujukan yang menjadi tolok ukur dari Sekolah Menengah Atas (SMA) lain yang terdapat di Kabupaten Pacitan.

\section{HASIL DAN PEMBAHASAN}

Pelaksanaan PKM berkaitan dengan penguatan pendampingan kurikulum 2013 ini direncanakan dalam 3 tahap besar yang masing-masing mempunyai bentuk kegiatan yang berbeda. Tahap Persiapan; Tahap persiapan ini berkaitan dengan hal yang perlu dipersiapkan dalam rangka pelaksanaan PKM ini. Persiapan awal yang dilakukan adalah survei awal ke tempat atau lokasi PKM untuk mendapatkan data awal. Setelah mendapatkan data awal baru menyusun rencana kegiatan PKM sesuai dengan kondisi permasalahan yang dihadapi sekolah dalam pelaksanaan Kurikulum 2013 revisi yang pada umumnya masih belum banyak SMA yang mengimplementasikannya di Kabupaten Pacitan. Pada tahap ini juga dilakukan perekrutan mahasiswa yang berkompetensi untuk mendampingi untuk melaksanakan PKM ini. Oleh karena, mahasiswa FKIP UNS telah mendapatkan materi Kurikulum 2013 revisi sehingga dapat mendampingi guru dan siswa di Kabupaten Pacitan dalam memahami Kurikulum 2013 revisi.

Tahap Pelaksaaan; Tahap pelaksanaan adalah inti dari PKM ini yang akan dilakukan di sekolah. Kegiatan inti adalah pendampingan pendekatan scientific approach yang menjadi permasalahan utama yang dialami oleh guru-guru di Kabupaten Pacitan, Kegiatan inti ini berupa pelatihan, workshop, dan focus group discussion (FGD) yang dilakukan di Kabupaten Pacitan oleh Tim PKM dibantu oleh mahasiswa dalam pelaksanaan di lapangan. Detail pelaksanaan PKM ini terurai dalam gambaran ipteks yang akan ditranfer kepada guru-guru di Kabupaten Pacitan. 
Tahap Evaluasi; Tahap evaluasi adalah tahap akhir dari PKM ini yang akan dilakukan oleh dosen dan mahasiswa mengenai penilaian terhadap apa yang telah dilakukan sebelum dan sesudah di sekolah serta keikutsertaan guru dan siswa dalam pelatihan dan bimbingan dalam pelaksanaan Kurikulum 2013 revisi. Hal-hal yang terdapat dalam tahap pelaksanaan akan dibahas dalam tahap evaluasi, termasuk apabila terdapat kritik dan masukan baik dari pihak sekolah, guru, siswa, maupun dari pihak tim penelitian dari UNS. Data-data yang diperoleh dalam ketiga tahap tersebut kemudian dijadikan dasar dalam pembuatan artikel ilmiah sebagai luaran dalam penelitian PKM di SMA Kabupaten Pacitan.

Pelaksanaan program PKM ini direncanakan berlangsung beberapa kali pertemuan yang dimulai pada awal tahun 2018. Pelaksanaan tersebut diawali dengan perencanaan, pelaksanaan, dan diakhiri dengan evaluasi. Berikut jadwal pelaksanaan PKM berkaitan dengan Kurikulum 2013 revisi di Kabupaten Pacitan, Provinsi Jawa Timur.

Target dan luaran PKM ini dapat dijabarkan menjadi dua hal, yaitu produk kegiatan PKM dan hasil program PKM. Adapun jabaran dari luaran tersebut dipaparkan yaitu, (1) Indikator tercapainya kegiatan ini sudah dirumuskan oleh tim pelaksana PKM. Adapun indikator capaian program kegiatan PKM yang berjudul pendampingan pelaksanaan kurikulum 2013 revisi melalui implementasi scientific approach di SMA di Kabupaten Pacitan adalah (a) Guru dan siswa Sekolah Menengah Atas di Kabupaten Pacitan dapat memperoleh pemahaman mengenai kurikulum 2013 revisi dan cara implementasinya dalam proses belajar mengajar, khususnya proses belajar mengajar di SMA dengan menggunakan pendekatan scientific approach; (b) Guru dan siswa dapat memperoleh pengetahuan tentang hakikat kurikulum 2013 revisi seperti yang telah dicanangkan oleh pemerintah melalui Kementerian Pendidikan dan Kebudayaan; (c) Guru dapat menyusun desain kegiatan proses belajar-mengajar sesuai dengan tujuan dan indikator yang terdapat dalam kurikulum 2013 revisi dengan menggunakan pendekatan scientific approach bagi siswa SMA di Kabupaten Pacitan; dan (d) Guru dan siswa dapat mengimplementasikan Kurikulum 2013 revisi dengan menggunakan pendekatan scientific approach untuk pembelajaran SMA di Kabupaten Pacitan.

Produk Kegiatan PKM yaitu Modul atau buku pedoman mengenai pendampingan pelaksanaan kurikulum 2013 revisi dengan menggunakan scientific approach bagi SMA di Kabupaten Pacitan. Selain itu adalah Artikel jurnal pengabdian mengenai kegiatan pendampingan pelaksanaan kurikulum 2013 revisi dengan menggunakan scientific approach bagi SMA di Kabupaten Pacitan.

Hasil Program PKM merupakan hasil kegiatan pendampingan pelaksanaan kurikulum 2013 revisi dengan menggunakan scientific approach bagi SMA di 
Kabupaten Pacitan., dijabarkan dalam 2 bagian, yaitu hasil kegiatan jangka pendek dan jangka panjang. Secara garis besar hasil kegiatan ini dapat dijabarkan yaitu dua bagian yaitu jangka pendek dan jangka panjang.

Dalam jangka pendek, guru dan siswa SMA di Kabupaten Pacitan dapat memperoleh pengertian mengenai kurikulum 2013 revisi dan tata cara mengimplementasikan dalam pembelajaran di SMA dengan menggunakan scientific approach. Hal ini diharapkan guru dapat mendesain pembelajaran menjadi sesuai dengan indikator dan tujuan yang terdapat dalam draf kurikulum 2013 revisi dengan menggunakan scientific approach, sehingga pembelajaran di SMA akan menjadi lebih efektif dan dapat mencapai tujuan pembelajaran seperti yang sudah dicanangkan oleh pemerintah.

Dalam jangka panjang, dalam jangka panjang dapat terus dilakukan dalam rangka memberikan alternatif bentuk sosialisasi dan implementasi Kurikulum 2013 revisi yang ditujukan untuk guru dan siswa di tingkat Sekolah Menengah Atas (SMA), khususnya di Kabupaten Pacitan, Jawa Timur. Dengan begitu, proses pembelajaran akan menjadi lebih efektif karena guru dan siswa sudah memiliki pemahaman mengenai bentuk kurikulum dan desain proses belajar-mengajar yang baik untuk mencapai tujuan pembelajaran.

Keberhasilan PKM ini juga tentunya berdampak pada Universitas Sebelas Maret, khususnya Research Group yang bernaung di bawah Fakultas Keguruan dan Ilmu Pendidikan. Kegiatan ini mencerminkan bahwa salah satu tanggung jawab perguruan tinggi terhadap masyarakat, dalam hal ini sekolah yang tewujud dalam kegiatan PKM ini, khususnya yang berkaitan penguatan implementasi Kurikulum 2013 revisi. Kegiatan ini juga mencerminkan bahwa kebutuhan akan pengetahuan berkaitan dengan Kurikulum 2013 revisi masih diperlukan oleh sekolah secara umum dan ini menjadi salah satu tanggung jawab dosen dan mahasiswa yang telah mendapatkan ilmunya di bangku kuliah atau di kampus.

\section{KESIMPULAN}

Pelaksanaan program PKM ini terdiri dari dosen dan mahasiswa Universitas Sebelas Maret Surakarta. Tahap evaluasi yang dilakukan adalah dengan melihat persiapan, proses pelaksanaan implementasi Kurikuum 2013 revisi di sekolahsekolah yang menjadi objek PKM. Tingkat keberhasilan PKM dapat dilihat dari pemahaman guru dan siswa dalam melaksanakan Kurikulum 2013 revisi dengan menggunakan scientific approach. Hal ini dapat dijadikan tolok ukur tingkat keberhasilan PKM karena di Kabupaten Pacitan, seperti terurai di awal bahwa masih banyak guru dan siswa belum memahami hakikat Kurikulum 2013 revisi. Keberhasilan PKM ini juga memberikan kontribusi dalam menyosialisasikan dan 
menyukseskan implementasi Kurikulum 2013 revisi yang telah dicanangkan pemerintah dan oleh Kementerian Pendidikan dan Kebudayaan ditargetkan semua satuan penddikan di semua tingkatan harus melaksanakan walaupun dari pemerintah yang baru menunda pelaksanaannya tetapi tetap perlu dilakukan untuk penguatan implementasinya. 


\section{DAFTAR PUSTAKA}

Amri, Sofan dan Ahmadi, Iif Khoiru. 2010. Konstruksi Pengembangan Pembelajaran. Jakarta: Prestasi Pustaka.

Hidayat, Sholeh. 2013. Pengembangan Kurikulum Baru. Bandung: PT Remaja Rosdakarya Bandung

Mulyasa. 2013. Pengembangan dan Implementasi Kurikulum 2013. Bandung: PT Remaja Rosdakarya

Uno, H. 2007. Model Pembelajaran Menciptakan Proses Belajar Mengajar yang Kreatif dan Efektif. Jakarta: Bumi Aksara.

Kemendikbud. 2013. Kerangka Dasar Kurikulum 2013. Kementerian Pendidikan dan Kebudayaan Direktorat Jenderal Pendidikan Dasar . Jakarta

Kunandar, 2013. Penilaian Autentik (Penilaian Hasil Belajar Peserta Didik Berdasarkan Kurikulum 2013). Rajawali Pers. Jakarta.

Peraturan Pemerintah No. 32 Tahun 2013 tentang perubahan Peraturan Pemerintah No. 19 Tahun 2005 Tentang Standar Nasional Pendidikan.

Permendikbud No. 65 Tahun 2013 Tentang Standar Proses Pendidikan Dasar dan Menengah.

Saddhono, Kundharu. 2014. Pembelajaran Keterampilan Berbahasa Indonesia: Teori dan Praktik. Yogyakarta; Graha Ilmu. 